\title{
Can Bicarbonate Enhance the Performance of Carob Seedlings Grown in Nutrient Solutions with Different Fe Concentrations?
}

\author{
Florinda Gama ${ }^{1}$ (1) Pedro José Correia ${ }^{1}$ - Teresa Saavedra ${ }^{1}$ - Susana Dandlen ${ }^{1} \cdot$ Amarilis de Varennes $^{2}$. \\ Gustavo Nolasco ${ }^{1} \cdot$ Maribela Pestana $^{1}$
}

Received: 2 March 2019 / Accepted: 11 September 2019

(C) Sociedad Chilena de la Ciencia del Suelo 2019

\begin{abstract}
The aim of this work was to assess the effect of bicarbonate (Bic) ion on the nutritional status and performance of carob-tree seedlings, a species that normally grows in calcareous soil without exhibiting iron chlorosis symptoms. Seedlings were previously grown in nutrient solution with a small concentration of $\mathrm{Fe}(0.5-1 \mu \mathrm{M})$ to induce a moderate chlorosis. Afterwards, two experiments were established: in experiment 1, plants were grown for 21 days in the following treatments: Fe deficiency (Fe0), $0.5 \mu \mathrm{M} \mathrm{Fe}, 5 \mu \mathrm{M} \mathrm{Fe}$, and $5 \mu \mathrm{M}$ Fe plus calcium carbonate $\left(\mathrm{CaCO}_{3}\right)$. After assessing these results, a second experiment was conducted for 91 days, with the following treatments: $\mathrm{Fe} 0,1 \mu \mathrm{M} \mathrm{Fe}, 40 \mu \mathrm{M} \mathrm{Fe}$ and $40 \mu \mathrm{M}$ Fe plus $\mathrm{CaCO}_{3}$ and sodium bicarbonate $\left(\mathrm{NaHCO}_{3}\right)$. Chlorophyll of young leaves, biomass and mineral composition of leaves, stems and roots were assessed in both experiments. The ferric chelate reductase root activity (FC-R) and the genetic expression of calmodulin-regulated $\mathrm{Ca}^{2+}$ ATPase pump (ACA gene) were evaluated in experiment 2. Fe-deficient plants exhibited reduced growth and enhanced macronutrients in leaves. Root micronutrient homeostasis changed as an adaptive mechanism in carob. The addition of bicarbonate did not aggravate Fe chlorosis, as leaf chlorophyll increased significantly. Root FC-R activity and ACA gene expression was not enhanced under Fe deficiency induced by bicarbonate ( $\mathrm{Fe} 40+\mathrm{BicNa}$ ) which suggest a positive effect of bicarbonate in the metabolism of this crop. Nevertheless, small $\mathrm{Fe}$ concentrations ( $\mathrm{Fe} 1$ ) induced a higher ACA gene expression thus indicating some stress response signalling.
\end{abstract}

Keywords Calmodulin-regulated $\mathrm{Ca}^{2+}$-ATPase pump $\cdot$ Ceratonia siliqua $\mathrm{L} \cdot \cdot \mathrm{HCO}_{3}{ }^{-} \cdot$ Iron chlorosis $\cdot$ Nutrients $\cdot$ Root FC-R

\section{Introduction}

There are several soil factors that promote iron $(\mathrm{Fe})$ deficiency in field crops. Fe concentrations in alkaline soils ( $\mathrm{pH}$ between 7.5 and 8.5) are approximately $10^{-10.4} \mathrm{M}$ and insufficient for optimal plant growth, which require a Fe soluble range in the medium between $10^{-9}$ and $10^{-4} \mathrm{M}$ (Guerinot and Yi 1994). In calcareous soils, the bicarbonate ion $\left(\mathrm{HCO}_{3}{ }^{-}\right)$aggravates the situation and is the most prevalent cause of Fe chlorosis in

Florinda Gama

fmgama@ualg.pt

1 MeditBio - Center for Mediterranean Bioresources and Food, Universidade do Algarve, Campus de Gambelas, 8005-139 Faro, Portugal

2 LEAF - Linking Landscape, Environment, Agriculture and Food, University of Lisbon, Tapada da Ajuda, 1349-017 Lisbon, Portugal fruit tree crops. Soluble ferric $\left(\mathrm{Fe}^{3+}\right)$ and ferrous $\left(\mathrm{Fe}^{2+}\right)$ salts react rapidly with calcium carbonate to form $\mathrm{Fe}$-hydroxides, which make Fe unavailable to plants (Bastani et al. 2018; Granja and Covarrubias 2018; Pestana et al. 2004). In nutrient solutions, $\mathrm{HCO}_{3}^{-}$(added as calcium or sodium carbonate) induces $\mathrm{Fe}$ chlorosis in several horticultural crops like quince (Donnini et al. 2009), maize, sorghum and barley (Alhendawi et al. 2008), grapevine (Ollat et al. 2003) and citrus (MartínezCuenca et al. 2013; Pestana et al. 2005). In tomato, pea and cucumber, it was demonstrated that $\mathrm{HCO}_{3}{ }^{-}$could induce $\mathrm{Fe}$ deficiency by inhibiting the expression of root ferric reductase enzyme (FC-R), the $\mathrm{Fe}$ transporter (IRT) and the $\mathrm{H}^{+}$-ATPase (HA) genes (Lucena et al. 2007). The bicarbonate ion $\left(\mathrm{HCO}_{3}{ }^{-}\right)$increases apoplast $\mathrm{pH}$ thus restricting Fe translocation and trapping it in the apoplast of maize root cells (Kosegarten and Koyro 2001), and an alkalinization of the xylem sap of intact maize seedlings due to the presence of $\mathrm{HCO}_{3}{ }^{-}$was observed by Wegner and Zimmermann (2004). For example, in the citrus genotype Forner-Alcaide 5, which is 
known to be tolerant to calcareous soils, the addition of $10 \mathrm{mM} \mathrm{NaHCO}$ led to a reduction of $\mathrm{Fe}^{2+}$ uptake and shoot growth, as well as an enhanced expression of FRO2 gene (Martínez-Cuenca et al. 2013). In the grapevine rootstock 140 Rugeri grown in the presence of $\mathrm{HCO}_{3}{ }^{-}$, the lack of Fe in the solution led to a change of the root metabolism through an enhancement of root biomass and malic acid concentration, but interestingly, leaf chlorophyll was incremented (Covarrubias and Rombolà 2013). Mineral composition of plant tissues may be affected due to Fe deficiency, but in some cases, a balanced nutritional status is maintained (Granja and Covarrubias 2018; Covarrubias and Rombolà 2013).

Plants that preferentially grow in calcareous soil (calcicoles) can cope with nutritional constraints like less Fe availability and high soil $\mathrm{Ca}$ and $\mathrm{HCO}_{3}{ }^{-}$. These plants are more efficient on Fe uptake and use, and the toxic effect of bicarbonate on root growth is negligible (Marschner 2012). Ceratonia siliqua (L.) is a fruit tree species which grows in the Mediterranean ecosystem that is well adapted to limestone soils. Due to its particular features, this crop is efficient in using N and P (Correia and Martins-Loução 2005) which is also a particularity of calcicole species. Moreover, field-grown rootstock, grafted or ungrafted, do not develop symptoms of Fe chlorosis (Correia et al. 2014), indicating a conservative and optimized strategy regarding the use of Fe.

Fe deficiency normally enhanced the expression of several genes, such as the ferric reductase oxidase (FRO), HA and phosphoenolpyruvate carboxylase (PEPC), which encodes an increase of the activity of the corresponding enzymes, which may be regarded as an adaptive mechanism to Fe starvation (Michel et al. 2019; Martínez-Cuenca et al. 2013). Furthermore, other genes might also be involved. Several calmodulin-binding proteins may be important for understanding the molecular mechanisms involved in abiotic stress tolerance in plants (Virdi et al. 2015). In the susceptible Poncirus trifoliata rootstock, several genes related to cell wall modifications were overexpressed in Fe-deficient plants (Forner-Giner et al. 2010). One of these genes expresses a calmodulin-regulated $\mathrm{Ca}^{2+}$-ATPase pump, present in the plasma membrane that regulates the concentration of $\mathrm{Ca}^{2+}$ in the cytosol. $\mathrm{Ca}^{2+}$-ATPase pumps belong to either the P2AATPase or P2B-ATPase group, where the latter possesses a structural difference with an extended $\mathrm{N}$-terminus which binds calmodulin serves as an auto inhibitory of pump activity (Bose et al. 2011).

Young carob plants are able to grow in calcareous soils without symptoms of iron deficiency and frequently, crystals of calcium oxalate are observed close to the primordia of reproductive buds in mature trees, suggesting an efficient mechanism to sequester the excess of calcium (unpublished results). Besides, in previous experiments, carob plants growing with low Fe availability ( $1 \mu \mathrm{M}$ of $\mathrm{Fe}$ ) did not show severe Fe chlorosis symptoms as expected (Pestana et al. 2012), and there was an increase in organic acid concentrations in root and shoots (Correia et al. 2014). However, the behaviour of carob seedlings under Fe shortage is not well-known and stress gene expressions have never been described.

We propose to conduct two experiments using carob seedlings previously grown under low Fe concentration in order to induce a moderate Fe stress during the initial stages of seedling development using either calcium carbonate (Bic) or calcium carbonate plus sodium bicarbonate $(\mathrm{BicNa})$ as the sources of the bicarbonate ion. We expect to describe the physiological and morphological responses to Fe efficiency and understand which mechanisms are involved in the establishment and recovery of the seedlings under high $\mathrm{HCO}_{3}{ }^{-}$ availability. Moreover, we want to assess if $\mathrm{Fe}$ availability can modulate the expression of the calmodulin-regulated $\mathrm{Ca}^{2+}$-ATPase pump gene (ACA). Ultimately, we believe to provide new insights into the strategy of this crop in calcareous and alkaline soil conditions.

\section{Materials and Methods}

\subsection{Seed Germination and Growth Conditions}

For both experiments (1 and 2) conducted under glasshouse conditions, seeds were obtained from a commercial mixture and for germination, seeds were immersed in water heated to $80{ }^{\circ} \mathrm{C}$ for $1 \mathrm{~h}$ and afterwards transferred into water at room temperature and kept for $24 \mathrm{~h}$. Then, seeds were sown in trays containing vermiculite which was disinfected by spraying with a solution of fosethyl-aluminium $\left(2 \mathrm{~g} \mathrm{~L}^{-1}\right)$. The substrate was irrigated with distilled water to maintain adequate moisture content until germination.

\subsection{Experiment 1}

Carob seedlings with 1-2 pairs of leaves (plus the cotyledons) and $5 \mathrm{~cm}$ tall were transferred to $20-\mathrm{L}$ containers with $1 / 4$ strength Hoagland's nutrient solution. The solution was prepared using demineralized water with the following chemical composition (macronutrients in $\mathrm{mM}$ ): $1.25 \mathrm{Ca}\left(\mathrm{NO}_{3}\right)_{2} \cdot 4 \mathrm{H}_{2} \mathrm{O}$, $1.25 \mathrm{KNO}_{3}, 0.25 \mathrm{KH}_{2} \mathrm{PO}_{4}, 0.5 \mathrm{MgSO}_{4} \cdot 7 \mathrm{H}_{2} \mathrm{O}$ and (micronutrients in $\mu \mathrm{M}$ ): $11.5 \mathrm{H}_{3} \mathrm{BO}_{3}, 0.2 \mathrm{ZnSO}_{4} \cdot 7 \mathrm{H}_{2} \mathrm{O}, 0.1$ $\mathrm{CuSO}_{4} \cdot 5 \mathrm{H}_{2} \mathrm{O}, 9 \mathrm{MnCl}_{2} \cdot 4 \mathrm{H}_{2} \mathrm{O}$ and $0.02\left(\mathrm{NH}_{4}\right) 6 \mathrm{Mo}_{7} \mathrm{O}_{27} \cdot \mathrm{H}_{2} \mathrm{O}$. Iron was added as Fe (III)-EDDHA (Basafer® from Compo, with $6 \%$ of Fe; $5.0 \%$ of Fe chelated by ortho-ortho EDDHA) at $0.5 \mu \mathrm{M}$, and plants were grown in these conditions for 60 days until the appearance of chlorosis (pre-treatment stage but without cotyledons, which were gradually senesced during this stage). Then, they were transferred into a newly made fullstrength Hoagland's nutrient solution with the following chemical composition (macronutrients in $\mathrm{mM}$ ): $5 \mathrm{Ca}\left(\mathrm{NO}_{3}\right)_{2}$. $4 \mathrm{H}_{2} \mathrm{O}, 5 \mathrm{KNO}_{3}, 1 \mathrm{KH}_{2} \mathrm{PO}_{4}, 2 \mathrm{MgSO}_{4} \cdot 7 \mathrm{H}_{2} \mathrm{O}$ and 
(micronutrients in $\mu \mathrm{M}$ ): $46 \mathrm{H}_{3} \mathrm{BO}_{3}, 0.8 \mathrm{ZnSO}_{4} \cdot 7 \mathrm{H}_{2} \mathrm{O}, 0.4$ $\mathrm{CuSO}_{4} \cdot 5 \mathrm{H}_{2} \mathrm{O}, 0.9 \mathrm{MnCl}_{2} \cdot 4 \mathrm{H}_{2} \mathrm{O}$ and $\left(\mathrm{NH}_{4}\right) 6 \mathrm{Mo}_{7} \mathrm{O}_{27} \cdot \mathrm{H}_{2} \mathrm{O}$. At this time, four treatments were imposed: $\mathrm{Fe} 0(0 \mu \mathrm{M} \mathrm{Fe})$, $\mathrm{Fe} 0.5(0.5 \mu \mathrm{M} \mathrm{Fe}), \mathrm{Fe} 5(5 \mu \mathrm{M} \mathrm{Fe})$ and Fe5 plus $1 \mathrm{~g} \mathrm{~L}^{-1}$ $\mathrm{CaCO}_{3}(\mathrm{Fe} 5+\mathrm{Bic})$. For each treatment, 10 plants (replicates) were distributed by four 20-L containers, in a total of 40 plants under study. The initial $\mathrm{pH}$ of the nutrient solution was adjusted to 6.0 with $\mathrm{NaOH}(1 \mathrm{M})$ for $\mathrm{Fe} 0, \mathrm{Fe} 0.5$ and $\mathrm{Fe} 5$ (control) treatments. For Fe5 + Bic, the solution was not adjusted, and the $\mathrm{pH}$ value was approximately 7.0. The electrical conductivity (EC) was $2.0 \pm 0.1 \mathrm{dS} \mathrm{m}^{-1}$ for all treatments. The nutrient solution was aerated throughout the experiment. The $\mathrm{pH}$ and EC values were monitored daily and concerning the $\mathrm{Fe} 5+\mathrm{Bic}$, the nutrient solution was stirred before readings. This experiment was concluded after apical leaves of $\mathrm{Fe} 0$ displayed severe chlorosis (yellowing of leaf mesophyll).

\subsection{Experiment 2}

In the second experiment, seedlings with four leaves, without cotyledons (due to short lifespan and senescence) and $10 \mathrm{~cm}$ tall were transplanted to 20 -L containers and kept in fullstrength Hoagland's solution, with $1.0 \mu \mathrm{M}$ of Fe also for 60 days (pre-treatment stage). After this stage, the following treatments were imposed considering different $\mathrm{Fe}$ concentrations (in $\mu \mathrm{M}$ of $\mathrm{Fe}$ ): 0 (Fe0), 1 (Fe1), 40 (Fe40) and 40 plus $1 \mathrm{~g} \mathrm{~L}^{-1} \mathrm{CaCO}_{3}$ plus $10 \mathrm{mM} \mathrm{NaHCO}(\mathrm{Fe} 40+\mathrm{BicNa})$. Iron was also added to the solutions as Fe (III)-EDDHA. As plants were taller and had more leaves, the Fe concentration was incremented from 5 to $40 \mu \mathrm{M}$ in order to maintain green plants (Fe40, control plants). In the beginning of experiment 2, the $\mathrm{pH}$ of the solution was adjusted to 6.0 with $\mathrm{NaOH}$ (1 M) except for $\mathrm{Fe} 40+\mathrm{BicNa}\left(\mathrm{CaCO}_{3}\right.$ plus $\left.\mathrm{NaHCO}_{3}\right)$ in order to simulate natural calcareous soil conditions. In this case, the $\mathrm{pH}$ ranged between 8.0 and 8.5 throughout the experimental period whereas in $\mathrm{Fe} 0$ and $\mathrm{Fe} 1$, the $\mathrm{pH}$ decreased 0.3 values while in Fe40 treatment, no variation was observed. The EC varied from $2.0 \pm 0.1 \mathrm{dS} \mathrm{m}^{-1}$ for Fe0, Fel and Fe40 treatments while in $\mathrm{Fe} 40+\mathrm{BicNa}$, the EC ranged between 2.4 and $2.5 \mathrm{dS} \mathrm{m}^{-1}$. Solutions were renewed once halfway through the experiment which was enough due to the slow-growing nature of this specie. Thus, we expect a slow rate of nutrients demand. Each treatment consisted of 10 plants per container in a total of 40 plants under study.

\subsection{Plant Parameters}

Leaf chlorosis was evaluated using the portable SPAD-502 meter (Minolta Corp., Japan) in fully expanded young leaves and in mature leaves. SPAD readings were taken in two different leaflets in all plants of each treatment in both experiments. SPAD readings were converted to total chlorophyll $\left(\mu \mathrm{mol} \mathrm{m}{ }^{-2}\right.$ ) using the calibration curve: Chlorophyll $=0.45$ $\times \mathrm{SPAD}^{2}+1.11 \times \mathrm{SPAD}+27.3\left(\mathrm{R}^{2}=0.97 ; n=35 ;\right.$ $P<0.001)$ according to Correia et al. (2014). At the end of both experiments, stem, leaves and root dry weights (d.w.) were recorded as well as root length. Plants were harvested and separated into roots, stems and leaves and weighted for biomass assessment; root length determination and mineral composition of each plant organ were quantified at the end of the experiments (21 days and 91 days respectively for experiment 1 and 2).

\subsection{Root Ferric Chelate Reductase Activity (FC-R)}

The activity of root FC-R (EC 1.16.1.17) was measured by the formation of the $\mathrm{Fe}$ (II)-bathophenantrolinedisulfonate (BPDS) complex from Fe (III)-EDTA (Bienfait et al. 1983) at the end of the experiment 2. Measurements were performed with root tips excised with a razor blade from each plant. Each excised root tip (approximately with $2 \mathrm{~cm}$ and $0.013 \pm 0.006 \mathrm{~g}$ of fresh weight - f.w.) was incubated in an Eppendorf tube in the dark with $900 \mu \mathrm{L}$ of micronutrient-free $1 / 2$ strength Hoagland's nutrient solution, containing $300 \mu \mathrm{M}$ BPDS, $500 \mu \mathrm{M}$ Fe (III)-EDTA and $5 \mathrm{mM}$ MES, pH 6.0. After $2 \mathrm{~h}$ of incubation, sample absorbances were registered spectrophotometrically using a 535-nm wavelength. An extinction coefficient of $22.14 \mathrm{mM} \mathrm{cm}^{-1}$ was used. Blank controls without root tips were also used to correct for any unspecific $\mathrm{Fe}$ reduction. The FC-R activity was expressed in nmol Fe (II) $\min ^{-1} \mathrm{~g}^{-1}$.

\subsection{Mineral Composition}

Plant organs were separated into leaves (leaflets plus petiole), stems and roots. Plant material was washed in tap water, next in distilled water containing a non-ionic detergent, and then in $0.01 \mathrm{M} \mathrm{HCl}$. Finally, three rinses were carried out in distilled water. The dry weight of each part was determined after drying at $60{ }^{\circ} \mathrm{C}$ for at least $48 \mathrm{~h}$. Samples were ground and ashed at $450{ }^{\circ} \mathrm{C}$ and digested in $\mathrm{HCl} 1 \mathrm{M}$. Standardized procedures (A.O.A.C. 1990) were used to determine mineral composition. Nitrogen was analysed using the Kjeldahl method and concentrations of $\mathrm{K}, \mathrm{Ca}, \mathrm{Mg}, \mathrm{Zn}, \mathrm{Cu}, \mathrm{Mn}$ and $\mathrm{Fe}$ were determined by atomic absorption spectrometry (AAS - M Series, Pye Unicam Ltd., Cambridge, UK). Phosphorus was determined colorimetrically using the molybdo-vanadate method with a 375-nm wavelength light source (spectrophotometer U2000, Hitachi Ltd., Tokyo, Japan).

\subsection{Expression of mRNA of calmodulin-regulated $\mathrm{Ca}^{2+}$-ATPase pump (ACA)}

Plant RNA was extracted using the EZRNA Plant RNA Kit (OMEGA), following the manufacturer's guidelines, from approximately $300 \mathrm{mg}$ (f.w.) of roots using three biological 
replicates (100 $\mathrm{mg}$ per replicate) for each Fe treatment of experiment 2 . Total RNA preparations were cleaned up with Turbo DNA-free Kit (Applied Biosystems) according to manufacturer instructions. Each RNA sample was quantified using the NanoDrop 2000c Spectrophotometer (Thermo Scientific) at $260 \mathrm{~nm}$. The ratio of absorbance at $260 \mathrm{~nm}$ and $280 \mathrm{~nm}$, used to assess the purity of RNA, in all samples was greater than 1.80 .

Expression of ACA gene was based on the Citrus medica cDNA clone C31502B08, mRNA (accession number FC874904) and quantified by real-time reverse transcriptional polymerase chain reaction (RT-PCR) in an iCycler IQ (Biorad) using the iScript One-Step RT-PCR Kit with SYBR Green (Biorad) and included $200 \mathrm{nM}$ of each of the ACA forward and reverse primers. ACA Fwd 5'-CAAATGGG GACGTTCAGTTT-3' and ACA Rev 5'-AGTGCAAG AGCTCCCAGTGT-3'.

The amplifications were prepared in a total volume of $25 \mu \mathrm{L}$ containing $12.5 \mu \mathrm{L}$ of $2 \times$ SYBR Green master mix, $0.5 \mu \mathrm{L}$ of each amplification primer, $0.5 \mu \mathrm{L}$ of iScript reverse transcriptase and $1 \mu \mathrm{L}$ of the RNA template. The thermo cycling parameters were reverse transcription for $10 \mathrm{~min}$ at $50{ }^{\circ} \mathrm{C}$, denaturation for $5 \mathrm{~min}$ at $95^{\circ} \mathrm{C}$, followed by 40 cycles of $10 \mathrm{~s}$ denaturation at $95^{\circ} \mathrm{C}, 30 \mathrm{~s}$ for annealing at $52^{\circ} \mathrm{C}$ and $30 \mathrm{~s}$ at $72^{\circ} \mathrm{C}$ for extension.

The efficiency of amplification of the ACA primers was determined by the iCycler software based in the amplifications of a series of dilutions made with three replicas for each dilution. Specificity of the amplifications was assessed by the melting curve analysis. Relative quantification of ACA expression was done according to the method of Pfaffl (2001), using 18S RNA amplification as a normalizing gene. Conditions for 18S RNA amplification were the same as used for ACA, except for the annealing temperature at $59^{\circ}$ and the primers which were: $18 \mathrm{SFwd} \mathrm{5'-GACTACGT}$ CCCTGCCCTTTG-3' and 18SRev 5'-TGATAAGG TTCAATGGACTTCTTC-3'. The efficiency of amplification of the 18S RNA was determined in a similar manner as for the ACA primers.

\subsection{Statistical Analysis and Experimental Layout}

Containers were distributed in a completely random layout. The effects of treatments were evaluated by one-way analysis of variance and the means compared using the Duncan multiple-range test (DMRT) at $P<0.05$ (SPSS software version 17.0).

\section{Results}

The results obtained in experiment 1 , and subsequently in experiment 2, were complementary. Plant material with different ages was used. Seedlings in experiment 1 were younger and thus submitted to a moderate stress imposition. In experiment 2 , we simulate a severe stress using older plants for a longer time.

\subsection{Experiment 1}

At the beginning of this experiment (day 1), chlorophyll concentration for all treatments $\left(150<\right.$ chlorophyll $\left(\mu \mathrm{mol} \mathrm{m}{ }^{-2}\right)<$ 325 ) indicated some degree of leaf chlorosis in young leaves (Fig. 1) just before treatment imposition. Subsequently, chlorosis was accentuated in both $\mathrm{Fe} 0$ and $\mathrm{Fe} 0.5$ treatments, and plants which grew with $5 \mu \mathrm{M}$ of $\mathrm{Fe}(\mathrm{Fe} 5)$ without or with calcium carbonate $(\mathrm{Fe} 5+\mathrm{Bic})$ showed higher chlorophyll, respectively 205 and $575 \mu \mathrm{mol} \mathrm{m}{ }^{-2}$ at day 21 .

The initial measurement date (day 4 ) revealed symptoms of Fe chlorosis as in experiment 1. After 16 days of treatment imposition, plants of $\mathrm{Fe} 0$ and $\mathrm{Fe} 1$ treatments maintained a significant small chlorophyll concentration respectively, 65 and $92 \mu \mathrm{mol} \mathrm{m}{ }^{-2}$. By the end of the experiment, chlorophyll concentration in plants without or with low Fe concentration in the nutrient solution ( $\mathrm{Fe} 0$ and $\mathrm{Fe} 1)$ maintained the low values while in $\mathrm{Fe} 40$ and $\mathrm{Fe} 40+\mathrm{BicNa}$ plants, chlorophyll increased to approximately $740 \mu \mathrm{mol} \mathrm{m}{ }^{-2}$.

Plants of $\mathrm{Fe} 40$ and $\mathrm{Fe} 40+\mathrm{BicNa}$ treatments (in particular, Fe40) had also higher leaf number and dry weight and higher root length and root dry weight. This trend was consistently observed until the end of the experiment (91 days, Table 3 ). The $\mathrm{R} / \mathrm{S}$ ratio was significantly higher in the $\mathrm{Fe} 40+\mathrm{BicNa}$.

As shown in Table 4, N, K and Mg concentrations were high in leaves of $\mathrm{Fe} 0$ and $\mathrm{Fe} 1$ treatments (no data is available for $\mathrm{N}$ in stems and roots).

In stems, $\mathrm{P}$ and $\mathrm{Mg}$ were also higher in deficient $\mathrm{Fe}$ treatments, and apparently also K. Calcium was significantly higher in roots of $\mathrm{Fe} 40+\mathrm{BicNa}$ but not in stems or leaves. Regarding micronutrients, higher concentration of $\mathrm{Fe}$ was found in leaves of $\mathrm{Fe} 40+\mathrm{BicNa}$ which converted to Fe content also showed higher leaf value $(137 \pm 74 \mu \mathrm{g}$ per plant). In stems, the differences are not so clear but it seems that plants under Fe deficiency showed more $\mathrm{Cu}$. The same is also true in roots, and Fe was significantly higher in Fe40 plants (with or without Bic and $\mathrm{Na}$ ).

Plants grown without $\mathrm{Fe}(\mathrm{Fe} 0)$ incremented twofold the root activity of the FC-R enzyme (Fig. 3a) compared to the remaining plants, which present similar activity among them.

Using the Fe40 plants as reference (relative expression= 1), plants grown with $1 \mu \mathrm{M} \mathrm{Fe}(\mathrm{Fe} 1)$ showed an overexpression of ACA gene (Fig. 3b). However, in the presence of bicarbonate $(\mathrm{Fe} 40+\mathrm{BicNa})$, the expression level was not enhanced.

At the end of both experiments, severe symptoms of $\mathrm{Fe}$ deficiency, yellowing of mesophyll of young leaves, were 
Fig. 1 Time course of total chlorophll $\left(\mu \mathrm{mol} \mathrm{m}{ }^{-2}\right)$ in young leaves for treatments of experiment 1 . Values are means \pm $\mathrm{SE} ; n=5$. Means with the same letters are not signficantly different at $P<0.05$ (Duncan test)

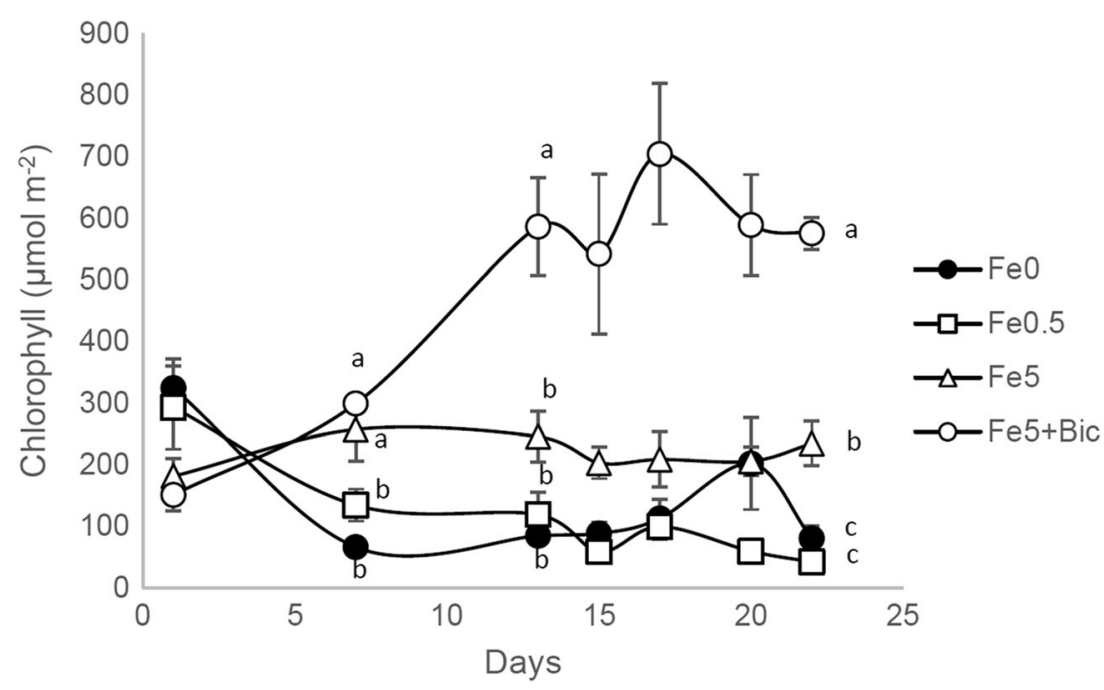

observed in plants grown without $\mathrm{Fe}$ in nutrient solution (Fig. 4). Plants growing with $\mathrm{Fe} 5$ showed moderate symptoms of Fe chlorosis (interveinal chlorosis of young leaves) while plants grown with $\mathrm{Fe} 40$ or with the addition of bicarbonate $(\mathrm{Fe} 5+\mathrm{Bic}$ and $\mathrm{Fe} 40+\mathrm{BicNa})$ remained green during all experiments.

\section{Discussion}

Both experiments showed that seedlings that grew under limited Fe supply $(0.5$ or $1 \mu \mathrm{M}$ of $\mathrm{Fe})$ or without $\mathrm{Fe}(0 \mu \mathrm{M} \mathrm{Fe})$ revealed clear $\mathrm{Fe}$ chlorosis symptoms in young leaves, which affected biomass accumulation and growth. The application of Fe just after treatment imposition, $40 \mu \mathrm{M}$ in experiment 2, conducted to a rapid recovery of leaf chlorophyll and plant performance improvement, although the presence of bicarbonate led to an increase of R/S ratio. In fact, carob seedlings are able to recover from radiation and water stress effects, due to multiple strategies (maintenance of electron transfer rate or proline increment) as found by Osório et al. (2011). The slow growing adaptive strategy shown by this crop explains why in experiment 1 no differences were observed in R/S after 21 days.

Similar recovering results can be found in calcicole species. For example, a total re-greening of young leaves was observed in Ulmus minor after Fe resupply (Venturas et al. 2014) and partially disappeared in Lupinus pilosus (Ding et al. (2019).

The higher concentration of macronutrients $(\mathrm{N}, \mathrm{P}, \mathrm{K}$ and $\mathrm{Mg}$ ) in leaves and stems of Fe-deficient treatments in comparison to $\mathrm{Fe} 5$ and $\mathrm{Fe} 40$ (with or without bicarbonate) was a response to Fe stress probably related to a dry weight reduction in stems and leaves and a concomitant "concentration effect." A similar response was reported in cucumber plants and in other crops (Tomasi et al. 2014 and references therein) explained by the depressed shoot dry matter production in $\mathrm{Fe}-$ deficient cucumber plants. In particular, P uptake was apparently reduced in plants grown in the presence of Bic (particularly visible in experiment 1 ), which is not entirely indicative of a calcicole behaviour (Neumann and Römheld 2012). It is possible that calcium phosphates produced in nutrient solution depressed $\mathrm{P}$ availability. $\mathrm{K}$ increase in leaves of Fe-deficient plants may be explained by the role of this cation in the regulation of osmotic adjustment to stress conditions. This response is probably not specific, since the same trend was registered in carob plants submitted to salinity stress (Correia et al. 2010). In roots, $\mathrm{N}$ followed a similar pattern as for aboveground tissues, but the depression of $\mathrm{K}$ accumulation in Fe-deficient plants, particularly in experiment 1, is not in accordance with the findings of Tomasi et al. (2014) for cucumber. More $\mathrm{Ca}$ was also found in leaves of Fe-deficient plants, particularly in experiment $2\left(19.1 \mathrm{~g} \mathrm{~kg}^{-1}\right.$ and

Table 1 Biomass parameters for each treatment at the end of experiment 1 (21 days). Means with different letter indicate significant differences at $P<0.05$ (Duncan test). $R / S$ root to shoot ratio

\begin{tabular}{lllllll}
\hline Treatments & Number of leaves & Stem d.w. $(\mathrm{g})$ & Root length $(\mathrm{cm})$ & Root d.w. $(\mathrm{g})$ & Leaf d.w. $(\mathrm{g})$ & R/S ratio \\
\hline $\mathrm{Fe} 0$ & $5.8 \mathrm{~b}$ & $0.13 \mathrm{~b}$ & $28.2 \mathrm{c}$ & $0.19 \mathrm{a}$ & $0.44 \mathrm{bc}$ & $0.33 \mathrm{a}$ \\
$\mathrm{Fe} 0.5$ & $5.7 \mathrm{~b}$ & $0.13 \mathrm{~b}$ & $34.2 \mathrm{~b}$ & $0.22 \mathrm{a}$ & $0.36 \mathrm{c}$ & $0.45 \mathrm{a}$ \\
$\mathrm{Fe} 5$ & $9.8 \mathrm{a}$ & $0.20 \mathrm{ab}$ & $46.7 \mathrm{a}$ & $0.28 \mathrm{a}$ & $0.64 \mathrm{a}$ & $0.33 \mathrm{a}$ \\
$\mathrm{Fe} 5+\mathrm{Bic}$ & $9.3 \mathrm{a}$ & $0.27 \mathrm{a}$ & $40.8 \mathrm{ab}$ & $0.26 \mathrm{a}$ & $0.60 \mathrm{ab}$ & $0.30 \mathrm{a}$ \\
\hline
\end{tabular}


Table 2 Mineral composition of roots, stems and leaves in treatments of experiment 1 (after 21 days of Fe treatments imposition). In each organ and nutrient, means with a different letter indicate significant differences at $P<0.05$ between Fe concentrations (Duncan test)

\begin{tabular}{|c|c|c|c|c|c|c|c|c|c|}
\hline & $\begin{array}{l}\mathrm{N} \\
\mathrm{g} \mathrm{kg}^{-1} \text { d.w. }\end{array}$ & $\mathrm{P}$ & $\mathrm{K}$ & $\mathrm{Mg}$ & $\mathrm{Ca}$ & $\begin{array}{l}\mathrm{Cu} \\
\mathrm{mg} \mathrm{kg}\end{array}$ & $\mathrm{Zn}$ & $\mathrm{Mn}$ & $\mathrm{Fe}$ \\
\hline \multicolumn{10}{|l|}{ Roots } \\
\hline $\mathrm{Fe} 0$ & $44.1 \mathrm{a}$ & $15.1 \mathrm{a}$ & $26.2 d$ & $3.6 \mathrm{~b}$ & $16.9 \mathrm{ab}$ & $214 a$ & $314 a$ & $850 \mathrm{a}$ & $204 b$ \\
\hline $\mathrm{Fe} 0.5$ & $45.0 \mathrm{a}$ & $15.1 \mathrm{a}$ & $30.7 \mathrm{c}$ & $4.2 \mathrm{ab}$ & $14.9 \mathrm{~b}$ & $182 \mathrm{a}$ & $254 \mathrm{ab}$ & $1028 \mathrm{a}$ & $212 b$ \\
\hline $\mathrm{Fe} 5$ & $34.7 b$ & $14.4 \mathrm{a}$ & $40.4 b$ & $5.4 \mathrm{a}$ & $24.0 \mathrm{a}$ & $39 b$ & $194 b$ & $873 a$ & $345 a$ \\
\hline $\mathrm{Fe} 5+\mathrm{Bic}$ & $36.4 b$ & $5.2 \mathrm{~b}$ & $48.7 \mathrm{a}$ & $4.7 \mathrm{ab}$ & $16.5 \mathrm{ab}$ & $33 b$ & $79 \mathrm{c}$ & $1119 \mathrm{a}$ & $252 b$ \\
\hline \multicolumn{10}{|l|}{ Stems } \\
\hline $\mathrm{Fe} 0$ & $36.1 \mathrm{a}$ & $10.0 \mathrm{~b}$ & $24.1 b$ & $3.2 \mathrm{a}$ & $8.9 \mathrm{~b}$ & $4 a$ & $58 \mathrm{a}$ & $33 a$ & $78 \mathrm{a}$ \\
\hline $\mathrm{Fe} 0.5$ & $34.6 \mathrm{a}$ & $13.0 \mathrm{a}$ & $28.0 \mathrm{a}$ & $2.8 \mathrm{ab}$ & $6.5 b$ & $3 a$ & $60 \mathrm{a}$ & $33 a$ & $91 \mathrm{a}$ \\
\hline $\mathrm{Fe} 5$ & $25.3 b$ & $10.1 \mathrm{~b}$ & $26.0 \mathrm{ab}$ & $2.3 b$ & $9.0 \mathrm{~b}$ & $7 \mathrm{a}$ & $55 \mathrm{a}$ & $31 \mathrm{a}$ & $86 a$ \\
\hline $\mathrm{Fe} 5+\mathrm{Bic}$ & $24.1 \mathrm{~b}$ & $4.7 \mathrm{c}$ & $25.1 \mathrm{~b}$ & $2.1 \mathrm{~b}$ & $12.6 \mathrm{a}$ & $5 \mathrm{a}$ & $34 \mathrm{~b}$ & $40 \mathrm{a}$ & $71 \mathrm{a}$ \\
\hline \multicolumn{10}{|l|}{ Leaves } \\
\hline $\mathrm{Fe} 0$ & $36.4 b$ & $5.3 b$ & $31.5 \mathrm{a}$ & $5.3 \mathrm{a}$ & $23.0 \mathrm{a}$ & $4 a$ & $60 \mathrm{a}$ & $183 \mathrm{a}$ & $57 \mathrm{a}$ \\
\hline $\mathrm{Fe} 0.5$ & $38.8 \mathrm{a}$ & $9.2 \mathrm{a}$ & $29.8 \mathrm{a}$ & $5.1 \mathrm{a}$ & $23.3 \mathrm{a}$ & $2 \mathrm{a}$ & $65 \mathrm{a}$ & $202 \mathrm{a}$ & $58 \mathrm{a}$ \\
\hline $\mathrm{Fe} 5$ & $28.6 \mathrm{c}$ & $7.6 \mathrm{a}$ & $21.1 \mathrm{~b}$ & $4.3 b$ & $21.8 \mathrm{a}$ & $3 a$ & $49 a b$ & $210 \mathrm{a}$ & $43 a$ \\
\hline $\mathrm{Fe} 5+\mathrm{Bic}$ & $28.2 \mathrm{c}$ & $3.4 \mathrm{~b}$ & $20.8 b$ & $3.7 b$ & $16.5 b$ & $4 a$ & $31 \mathrm{~b}$ & $341 \mathrm{a}$ & $48 \mathrm{a}$ \\
\hline
\end{tabular}

$22.7 \mathrm{~g} \mathrm{~kg}^{-1}$ respectively for $\mathrm{Fe} 0$ and $\mathrm{Fe} 1$ ) as a probable result of Fe stress and tissue concentration; however, Ca accumulation was observed in roots (experiment 2) or stems (experiment 1) of plants, which grew in the presence of bicarbonate. It seems that under shortage of $\mathrm{Fe}, \mathrm{Ca}$ is translocated from roots to leaves and concurrently, under excess (+Bic treatments), $\mathrm{Ca}$ is retained in roots (experiment 2). Uptake of $\mathrm{Ca}$ is proportional to $\mathrm{Ca}$ availability in the soil solution, and excess of $\mathrm{Ca}$ absorption may lead to the formation of crystalline Ca oxalate (Paiva 2019). Field-grown carob trees often show large amounts of those crystals which accumulate in the vicinity of the pre-emergent reproductive buds in lignified branches (unpublished results). Since the maintenance of low cytosolic Ca is imperative for the adaptation to Ca-rich soils (Lee 1998), the strategy of carob may include some sort of Casequestering at root level.

Apparently, root micronutrient homeostasis was changed. Carob seems to increase $\mathrm{Cu}$ uptake when facing Fe deficiency, accumulating $\mathrm{Cu}$ in roots viewed in both experiments and stems in experiment 2. This response was reported by other authors (Cohu and Pilon 2007; Pestana et al. 2013), and it was attributed to the affinity of different enzymatic systems either for $\mathrm{Fe}$ or for $\mathrm{Cu}$. In both experiments, it was noticed that $\mathrm{Cu}$ values in shoot tissues were low. Although no visual symptoms of $\mathrm{Cu}$ deficiency were observed in these experiments, this result may be due to formation of $\mathrm{Cu}$ (II) EDDHA chelates, an unavailable form for plants, which is known to occur
Fig. 2 Time course of total chlorophyll $\left(\mu \mathrm{mol} \mathrm{m}{ }^{-2}\right)$ in young leaves for treatments of experiment 2. Values are means \pm SE; $n=10$. Means with the same letters are not significantly different at $P<0.05$ (Duncan test)

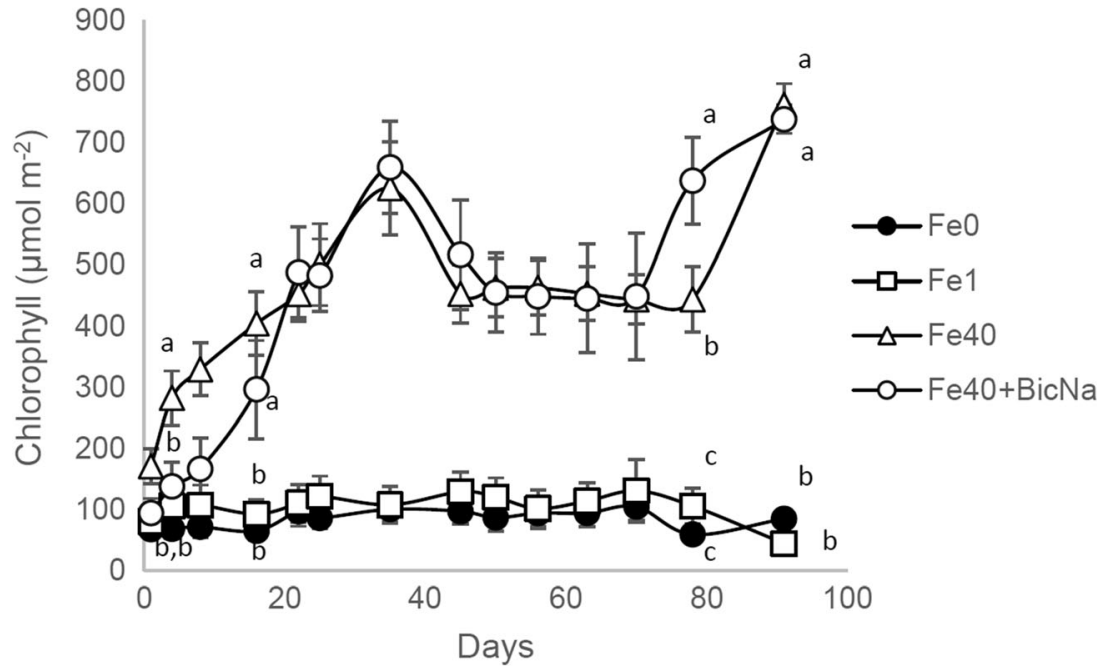


Table 3 Biomass parameters at the end of experiment 2 (91 days). Means with different letter indicate significant differences at $P<0.05$ (Duncan test). $R / S$ root to shoot ratio

\begin{tabular}{lllllll}
\hline Treatments & Number of leaves & Stem d.w. $(\mathrm{g})$ & Root length $(\mathrm{cm})$ & Root d.w. $(\mathrm{g})$ & Leaf d.w. $(\mathrm{g})$ & R/S ratio \\
\hline $\mathrm{Fe} 0$ & $4.7 \mathrm{~b}$ & $0.15 \mathrm{~b}$ & $12.3 \mathrm{~b}$ & $0.04 \mathrm{c}$ & $0.28 \mathrm{c}$ & $0.09 \mathrm{~b}$ \\
$\mathrm{Fe} 1$ & $4.0 \mathrm{~b}$ & $0.14 \mathrm{~b}$ & $17.0 \mathrm{~b}$ & $0.07 \mathrm{bc}$ & $0.32 \mathrm{c}$ & $0.15 \mathrm{~b}$ \\
$\mathrm{Fe} 40$ & $11.0 \mathrm{a}$ & $0.65 \mathrm{a}$ & $54.0 \mathrm{a}$ & $0.47 \mathrm{ab}$ & $1.57 \mathrm{a}$ & $0.21 \mathrm{~b}$ \\
$\mathrm{Fe} 40+\mathrm{BicNa}$ & $9.0 \mathrm{a}$ & $0.31 \mathrm{~b}$ & $41.7 \mathrm{a}$ & $0.60 \mathrm{a}$ & $0.97 \mathrm{~b}$ & $0.47 \mathrm{a}$ \\
\hline
\end{tabular}

when using commercial Fe chelates due to impurities of the isomers (Yunta et al. 2003).

Mn levels in leaves were in range of field conditions as reported by Correia et al. (2018) where leaf Mn in noncalcareous soils are relatively higher than in calcareous soils. Although the pattern of Mn was not conclusive, it was partially explained by the large variability within samples. In experiment 2, it was noticeable that the addition of bicarbonate (+Bic) lowered the Mn concentration in roots and leaves. $\mathrm{Zn}$ concentration seems to be depressed in the treatments with bicarbonate. In field studies, Fe concentrations in carob leaves may vary between 40 and $160 \mathrm{mg} \mathrm{kg}^{-1}$ d.w. in non-calcareous soils while in calcareous soils, the concentration is slightly lower varying between 35 and $100 \mathrm{mg} \mathrm{kg}^{-1}$ d.w. (Correia et al. 2018). The Fe concentrations were balanced out in leaves and stems in both experiments regardless of the amount of $\mathrm{Fe}$ in the nutrient solution. However, in the roots of Fesufficient plants, Fe5, and more expressively in Fe40 and $\mathrm{Fe} 40+\mathrm{BicNa}$, there was a threefold increase although no

Table 4 Mineral composition of roots, stems and leaves in treatments of experiment 2 (after 91 days of $\mathrm{Fe}$ treatments imposition). In each organ and nutrient, means with a different letter indicate significant differences toxicity was observed probably because much of the $\mathrm{Fe}$ is in the root apoplast (Römheld and Nikolic 2007).

Reduced growth and leaf chlorosis increase is a common effect of bicarbonate; however, the physiological response to bicarbonate exposure is variable and depends on the plant species (Dabrowska-Bronk et al. 2016). In the calcicole Lupinus pilosus, it was observed that plants grown with high $\mathrm{pH}$ and high calcium carbonate tend to reduce significantly the amount of $\mathrm{Fe}$ and $\mathrm{Mn}$ in roots and leaves and accumulate $\mathrm{Ca}$ in both of these organs (Ding et al. 2019). The addition of bicarbonate $(+\mathrm{Bic})$ did not aggravate leaf $\mathrm{Fe}$ chlorosis, nor reduced growth nor inhibited Fe uptake from the solution. This was particularly visible in experiment 1 as chlorophyll values in young leaves of $\mathrm{Fe} 5+\mathrm{Bic}$ plants increased, reaching values equal to those of $\mathrm{Fe} 40$ plants in experiment 2. Besides, symptoms of $\mathrm{Fe}$ chlorosis were no longer visible in $\mathrm{Fe} 5+\mathrm{Bic}$ plants whereas for $\mathrm{Fe} 5$ plants, chlorophyll values remained low. Plants that received bicarbonate showed similar or even higher chlorophyll concentration than the control plants in both experiments, and the recovery was fast with no limiting

at $P<0.05$ between Fe treatments (Duncan test). No data is available for $\mathrm{N}$ in roots and stems

\begin{tabular}{|c|c|c|c|c|c|c|c|c|c|}
\hline & $\begin{array}{l}\mathrm{N} \\
\mathrm{g} \mathrm{kg}^{-1} \text { d. w. }\end{array}$ & $\mathrm{P}$ & $\mathrm{K}$ & $\mathrm{Mg}$ & $\mathrm{Ca}$ & $\begin{array}{l}\mathrm{Cu} \\
\mathrm{mg} \mathrm{kq}\end{array}$ & $\mathrm{Zn}$ & Mn & $\mathrm{Fe}$ \\
\hline \multicolumn{10}{|l|}{ Roots } \\
\hline $\mathrm{Fe} 0$ & - & $10.5 \mathrm{a}$ & $25.1 \mathrm{a}$ & $4.3 \mathrm{a}$ & $5.4 \mathrm{~b}$ & $162 \mathrm{a}$ & $130 \mathrm{a}$ & $319 \mathrm{ab}$ & $409 \mathrm{~b}$ \\
\hline Fe1 & - & $11.6 \mathrm{a}$ & $19.6 \mathrm{a}$ & $3.6 \mathrm{a}$ & $9.5 \mathrm{~b}$ & $89 b$ & $162 \mathrm{a}$ & $396 a$ & $198 b$ \\
\hline $\mathrm{Fe} 40$ & $34.7^{\mathrm{a}}$ & $10.3 \mathrm{a}$ & $26.7 \mathrm{a}$ & $3.7 \mathrm{a}$ & $11.7 \mathrm{~b}$ & $23 \mathrm{c}$ & $124 \mathrm{a}$ & $471 \mathrm{a}$ & $1469 \mathrm{a}$ \\
\hline $\mathrm{Fe} 40+\mathrm{BicNa}$ & $38.6^{\mathrm{a}}$ & $5.0 \mathrm{~b}$ & $26.1 \mathrm{a}$ & $5.4 \mathrm{a}$ & $21.5 \mathrm{a}$ & $12 \mathrm{c}$ & $23 b$ & $113 b$ & $1251 \mathrm{a}$ \\
\hline \multicolumn{10}{|l|}{ Stems } \\
\hline $\mathrm{Fe} 0$ & - & $12.4 \mathrm{a}$ & $22.2 \mathrm{ab}$ & $5.3 \mathrm{a}$ & $16.6 \mathrm{a}$ & $16 \mathrm{a}$ & $54 \mathrm{a}$ & $26 \mathrm{a}$ & $118 \mathrm{a}$ \\
\hline $\mathrm{Fe} 1$ & - & $11.8 \mathrm{a}$ & $25.1 \mathrm{a}$ & $4.8 \mathrm{a}$ & $18.1 \mathrm{a}$ & $11 \mathrm{ab}$ & $58 \mathrm{a}$ & $21 \mathrm{a}$ & $99 \mathrm{a}$ \\
\hline $\mathrm{Fe} 40$ & $20.3^{\mathrm{a}}$ & $4.9 \mathrm{~b}$ & $15.7 b c$ & $1.8 \mathrm{~b}$ & $8.4 \mathrm{a}$ & $2 \mathrm{c}$ & $22 b$ & $16 \mathrm{a}$ & $92 \mathrm{a}$ \\
\hline $\mathrm{Fe} 40+\mathrm{BicNa}$ & $20.5^{\mathrm{a}}$ & $3.2 b$ & $11.3 \mathrm{c}$ & $3.9 \mathrm{ab}$ & $11.7 \mathrm{a}$ & $6 \mathrm{bc}$ & $34 b$ & $20 \mathrm{a}$ & $149 \mathrm{a}$ \\
\hline \multicolumn{10}{|l|}{ Leaves } \\
\hline $\mathrm{Fe} 0$ & $38.1 \mathrm{a}$ & $2.8 \mathrm{ab}$ & $41.1 \mathrm{a}$ & $5.9 \mathrm{a}$ & $19.1 \mathrm{ab}$ & $3 a$ & $36 \mathrm{a}$ & $134 \mathrm{ab}$ & $88 \mathrm{a}$ \\
\hline $\mathrm{Fe} 1$ & $35.5 \mathrm{a}$ & $3.5 \mathrm{a}$ & $33.5 \mathrm{a}$ & $6.2 \mathrm{a}$ & $22.7 \mathrm{a}$ & $3 a$ & $44 a$ & $201 \mathrm{a}$ & $79 a$ \\
\hline $\mathrm{Fe} 40$ & $21.9 b$ & $3.1 \mathrm{ab}$ & $14.9 \mathrm{~b}$ & $3.2 b$ & $13.0 \mathrm{bc}$ & $2 \mathrm{a}$ & $26 a b$ & $160 \mathrm{a}$ & $74 a$ \\
\hline $\mathrm{Fe} 40+\mathrm{BicNa}$ & $21.1 \mathrm{~b}$ & $1.5 \mathrm{~b}$ & $19.4 b$ & $2.6 \mathrm{~b}$ & $10.3 \mathrm{c}$ & 1a & $14 \mathrm{~b}$ & $79 b$ & $153 a$ \\
\hline
\end{tabular}

${ }^{\mathrm{a}} n=2$ 


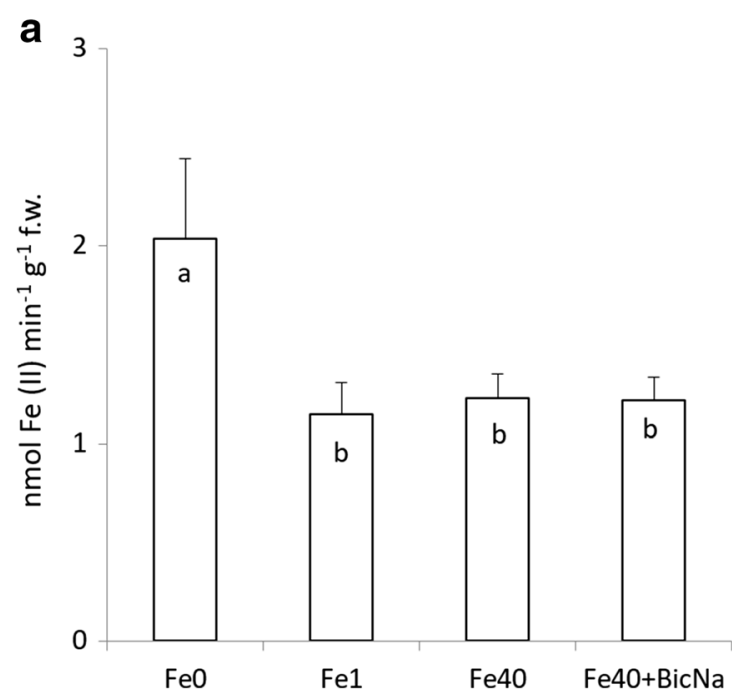

Fig. 3 Activity of root FC-R (a) and relative mRNA expression (b) of calmodulin-regulated $\mathrm{Ca}^{2+}$-ATPase gene (ACA) for all treatments at the end of experiment 2 . Columns with the same letter are not significantly

effect on plant observed. After being absorbed, $\mathrm{HCO}_{3}{ }^{-}$may be used in the synthesis of organic acids (Nikolic and Römheld 2007), incorporated into phosphoenolpyruvate and subsequently generating oxaloacetate and malate as part of the

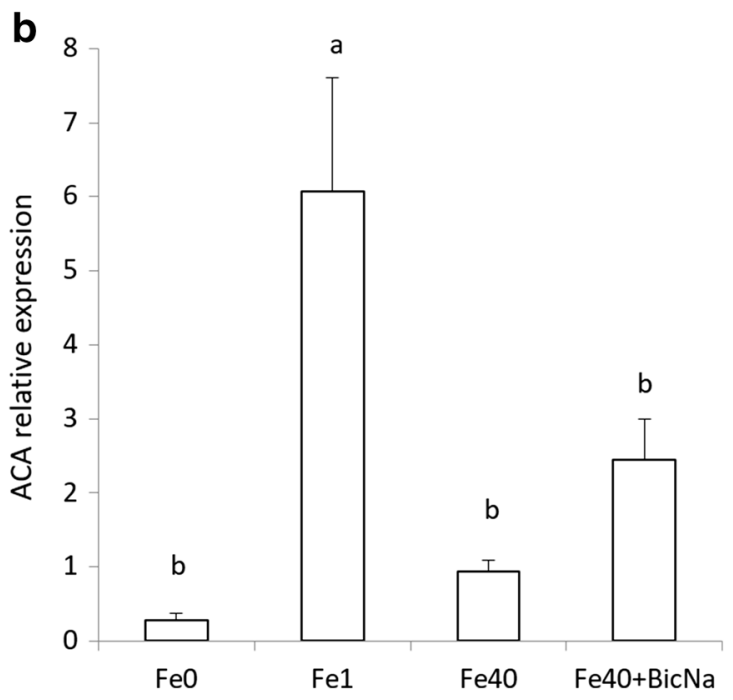

different at $P<0.05$ (Duncan test). Values are means \pm SE. For FC-R activity, $2<n<3$ and for ACA relative expression, $4<n<9$

pH-stat mechanism (Rombolà et al. 2002). Recently, it was demonstrated that carob trees produce an important pool of organic acids in roots and shoots as a response to Fe deficiency (Correia et al. 2014). Succinic and malic acid
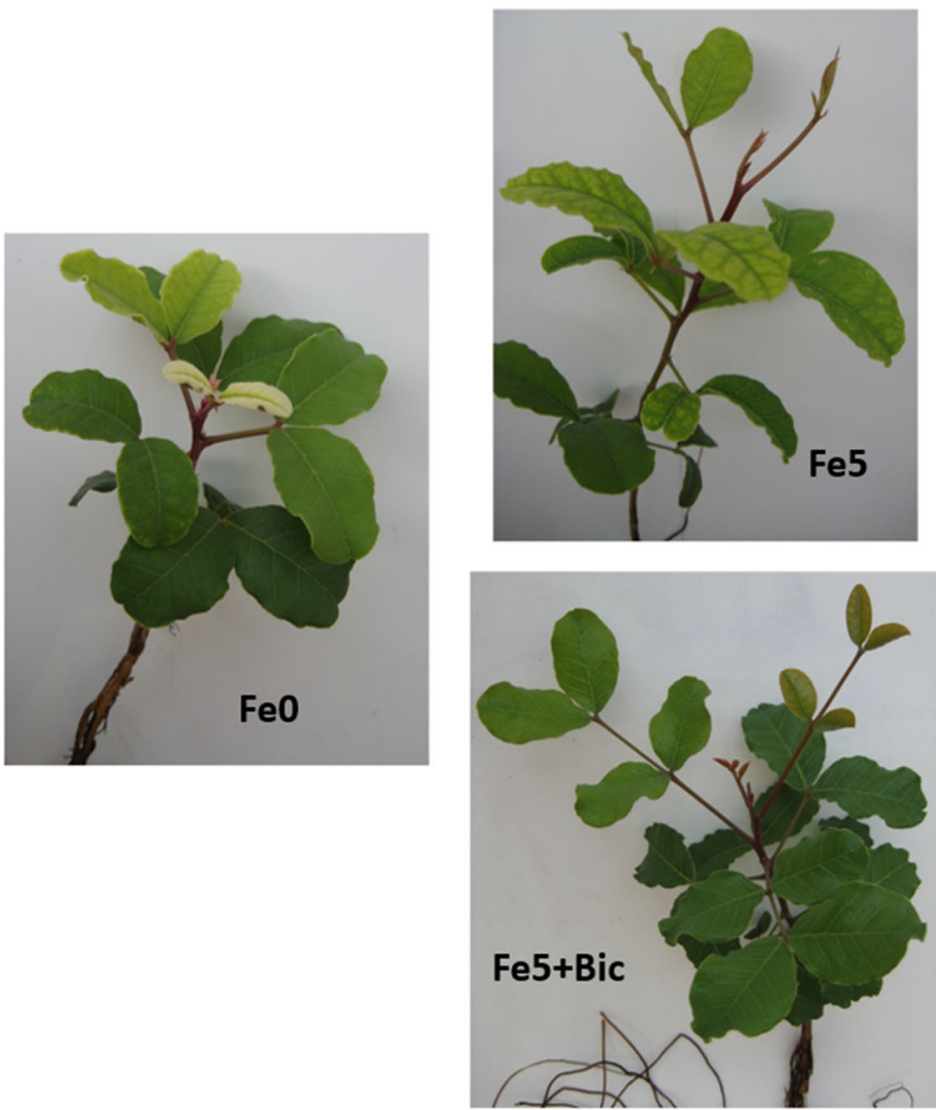

observed. Healthy plants were also obtained if bicarbonate $(\mathrm{Fe} 5+\mathrm{Bic})$ or bicarbonate plus $10 \mathrm{mM} \mathrm{NaHCO}_{3}(\mathrm{Fe} 40+\mathrm{BicNa})$ added in the nutrient solutions
Fig. 4 Chlorotic carob plants of $\mathrm{Fe} 0$ treatment at the end of both experiments. Plants of $\mathrm{Fe} 5$ in experiment 1 exhibit moderate symptoms of iron deficiency. In experiment 2, for Fe40 plants, no symptoms were
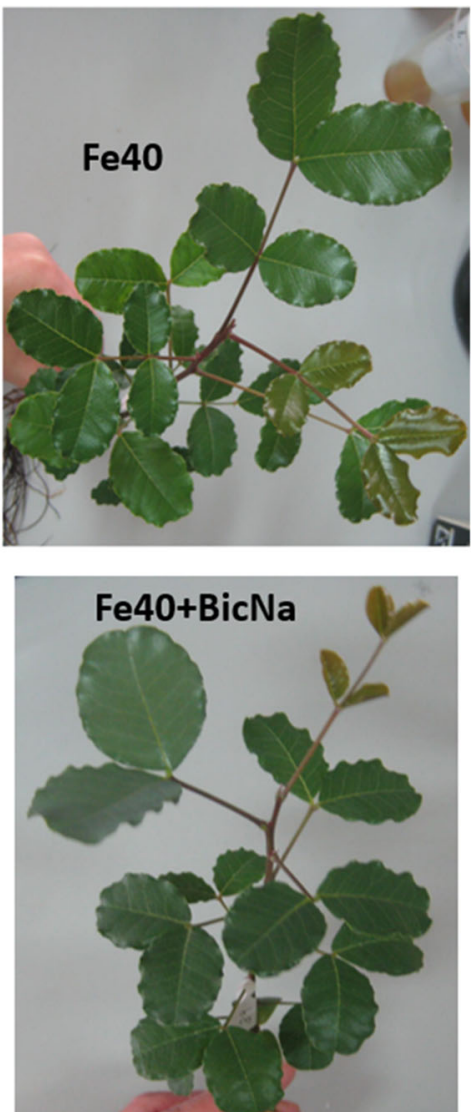
concentrations were particularly enhanced in young chlorotic leaves, but there was a consistent translocation pattern of acids from roots to basal, middle and young leaves as a response to Fe deficiency.

Bicarbonate blocks the Fe-deficiency-induced responses in roots (Kim and Guerinot 2007), and it has also been suggested that ethylene may be involved in the negative effect of $\mathrm{HCO}_{3}{ }^{-}$ in strategy I plants (García et al. 2013). Although there is some evidence that the increase in apoplast $\mathrm{pH}$ due to $\mathrm{HCO}_{3}{ }^{-}$induction may depress $\mathrm{Fe}^{3+}$ reduction (Mengel 1994), other studies indicate that the $\mathrm{pH}$ of the leaf apoplastic fluid is not affected by high $\mathrm{HCO}_{3}{ }^{-}$supply (Nikolic and Römheld 2002). Considering that the FC-R activity is pH dependent (Susin et al. 1996), the uptake of $\mathrm{HCO}_{3}{ }^{-}$at root level would inhibit the enzyme and thus depress the $\mathrm{Fe}^{3+}$ reduction. In carob, apparently, this was not the case since the activity of FC-R in $\mathrm{Fe} 40+\mathrm{BicNa}$ treatments was similar to control plants in experiment 2, demonstrating the lack of inhibitory effect of Bic on FC-R activity. This is contrast with the findings of Donnini et al. (2012) which found that in Parietaria diffusa (calcicole shrub) the activity of this enzyme was enhanced as compared to control Fe-sufficient plants. In fact, only in total absence of Fe, roots of carob showed higher FC-R activity demonstrating a clear stress signalling occurred in these conditions. This response is normally described in the literature, and it was also reported for this species in a concurrent paper by Pestana et al. (2012).

The results point to the absence of a stress signalling induced by the addition of $\mathrm{Ca}$ and or $\mathrm{Na}$ bicarbonate. Moreover, it seems that carob seedlings used bicarbonate to overcome the stressed conditions imposed by a Fe-deficiency growing conditions just after germination, as occurred in experiment 2 . In Poncirus trifoliata, a Citrus rootstock very susceptible to Fe deficiency, gene expression analysis showed that in Festressed plants $(0 \mu \mathrm{Fe})$, several genes, including a calmodulin-regulated $\mathrm{Ca}^{2+}$-ATPase pump (ACA), were overexpressed (Forner-Giner et al. 2010). In carob, no expression of ACA was registered either in $\mathrm{Fe} 0$ or in $\mathrm{Fe} 40+\mathrm{BicNa}$, but plants grown under $\mathrm{Fe}$ shortage ( $\mathrm{Fe} 1$ treatment in experiment 2) did show overexpression of ACA gene, which may indicate some stress signalling in those plants confirmed by the lack of chlorophyll recover in that treatment. Carob root cell walls are thick and $\mathrm{Ca}$ is tightly bound to pectins of the root cell wall thus enhancing rigidity (Rhizopoulou 2004) which supports the pattern of $\mathrm{Ca}$ accumulation. These features may play an important role in the resistance to several types of stress, including nutritional stress.

\section{Conclusions}

Taken together (experiments 1 and 2), the results may support a bicarbonate use efficiency strategy of carob seedlings.
Bicarbonate neither triggered growth inhibition nor aggravated Fe chlorosis in young leaves, which is the major finding of the present work and contrasts with most of the reported literature. Bicarbonate potentiated chlorophyll synthesis and, under these stress conditions, Ca metabolism is efficiently mobilized within plant organs. Moreover, Fe concentrations were not affected, due to bicarbonate addition in both experiments. Bicarbonate addition has positive effects on photosynthesis as referred by Wu and Xing (2012), and it has an important role in accelerating electron transfer to plastoquinone pools in PSII (for a review see Shevela et al. 2012). Presumably, bicarbonate potentiated the presence of $\mathrm{Fe}$, the solution and electron transfer originating a fast build-up of chlorophyll in young leaves. Concurrently, it seems that bicarbonate does not inhibit root ferric chelate reductase activity or change the enzyme optimal environment. However, small $\mathrm{Fe}$ concentration $(1 \mu \mathrm{M} \mathrm{Fe}$ in experiment 2) may conduct to overexpression of calmodulin-regulated $\mathrm{Ca}^{2+}$-ATPase pump gene meaning some Fe-stress signalling mechanism at membrane level.

Author Contributions P.J. Correia wrote the manuscript. F. Gama and T. Saavedra executed the hydroponic experiments and were responsible for the acquisition, analysis, and interpretation of data. G. Nolasco and S. Dandlen supervised the gene expression study. A. de Varennes was responsible for mineral composition analysis. P.J. Correia and M. Pestana contributed to the experimental layout and discussion of the results.

Funding information This study was funded by the National Project from the FCT - the Foundation for Science and Technology: PTDC/AGRALI/100115/2008 and FEDER Funds through the Operational Program for Competitiveness Factors - COMPETE. It also received funding from FCT as part of the Strategic Project: PEst-C/AGR/UI0115/2011. Florinda Gama is thankful to FCT for the PhD Grant SFRH/BD/89521/2012.

\section{Compliance with Ethical Standards}

Conflict of Interest The authors declare that they have no conflict of interest.

\section{References}

A.O.A.C (1990) Official methods of analysis of the Association of Official Analytical Chemists. Vol.1. K. Helrich (Ed.), Association of Official Analytical Chemists, 15th Ed. Arlington, Virginia

Alhendawi RA, Kirkby EA, Pilbeam DJ, Römheld V (2008) Effect of iron seed dressing and form of nitrogen-supply on growth and micronutrient concentration in shoots of sorghum grown in a calcareous sand culture. J Plant Nutr 31:1855-1865

Bastani S, Hajiboland R, Khatamian M, Saket-Oskoui M (2018) Nano iron $(\mathrm{Fe})$ complex is an effective source of $\mathrm{Fe}$ for tobacco plants grown under low Fe supply. J Soil Sci Plant Nutr 18:524-541. https://doi.org/10.4067/S0718-95162018005001602

Bienfait HF, Bino RJ, van der Bliek AM, Duivenvoorden JF, Fontaine JM (1983) Characterization of ferric reducing activity in roots of Fedeficient Phaseolus vulgaris. Physiol Plant 59:196-202. https://doi. org/10.1111/j.1399-3054.1983.tb00757.x 
Bose J, Pottosin II, Shabala SS, Palmgren MG, Shabala S (2011) Calcium efflux systems in stress signaling and adaptation in plants. Front Plant Sci 2. https://doi.org/10.3389/fpls.2011.00085

Cohu CM, Pilon M (2007) Regulation of superoxide dismutase expression by copper availability. Physiol Plant 129:747-755

Correia PJ, Martins-Loução MA (2005) The use of macronutrients and water in marginal Mediterranean areas: the case of carob-tree. Field Crop Res 91:1-6

Correia PJ, Gama F, Pestana M, Martins-Loução MA (2010) Tolerance of young (Ceratonia siliqua L.) carob rootstock to $\mathrm{NaCl}$. Agric Water Manag 97:910-916. https://doi.org/10.1016/j.agwat.2010.01.022

Correia PJ, Gama F, Saavedra T, Miguel MG, Paulo Da Silva J, Abadía A, De Varennes A, Pestana M (2014) Changes in the concentration of organic acids in roots and leaves of carob-tree under Fe deficiency. Funct Plant Biol 41:496. https://doi.org/10.1071/FP13204

Correia PJ, Saavedra T, Gama F, da Graça Miguel M, de Varennes A, Pestana M (2018) Biologically active compounds available in Ceratonia siliqua L. grown in contrasting soils under Mediterranean climate. Sci Hortic (Amsterdam). 235:228-234. https://doi.org/10.1016/j.scienta.2018.03.010

Covarrubias JI, Rombolà AD (2013) Physiological and biochemical responses of the iron chlorosis tolerant grapevine rootstock 140 Ruggeri to iron deficiency and bicarbonate. Plant Soil 370:305-315

Dąbrowska-Bronk J, Komar DN, Rusaczonek A, Kozłowska-Makulska A, Szechyńska-Hebda M, Karpiński S (2016) $\beta$-carbonic anhydrases and carbonic ions uptake positively influence Arabidopsis photosynthesis, oxidative stress tolerance and growth in light dependent manner. J Plant Physiol 203:44-54. https://doi. org/10.1016/j.jplph.2016.05.013

Ding W, Clode PL, Lambers H (2019) Is pH the key reason why some Lupinus species are sensitive to calcareous soil? Plant Soil 434:185201. https://doi.org/10.1007/s11104-018-3763-x

Donnini S, Castagna A, Ranieri A, Zocchi G (2009) Differential responses in pear and quince genotypes induced by Fe deficiency and bicarbonate. J Plant Physiol 166:1181-1193

Donnini S, de Nisi P, Gabotti D, Tato L, Zocchi G (2012) Adaptive strategies of Parietaria diffusa (M.\&K.) to calcareous habitat with limited iron availability. Plant Cell Environ 35:1171-1184. https:// doi.org/10.1111/j.1365-3040.2012.02481.x

Forner-Giner MA, Llosá MJ, Carrasco JL, Perez-Amador MA, Navarro L, Ancillo G (2010) Differential gene expression analysis provides new insights into the molecular basis of iron deficiency stress response in the citrus rootstock Poncirus trifoliata (L.) Raf. J Exp Bot 61:483-490

García MJ, Romera FJ, Stacey MG, Stacey G, Villar E, Alcántara E, Pérez-Vicente R (2013) Shoot to root communication is necessary to control the expression of iron-acquisition genes in strategy I plants. Planta 237:65-75. https://doi.org/10.1007/s00425-012$1757-0$

Granja F, Covarrubias JI (2018) Evaluation of acidifying nitrogen fertilizers in avocado trees with iron deficiency symptoms. J Soil Sci Plant Nutr 18:157-172. https://doi.org/10.4067/S071895162018005000702

Guerinot ML, Yi Y (1994) Iron: nutritious, noxious, and not readily available. Plant Physiol 104:815-820

Kim SA, Guerinot ML (2007) Mining iron: iron uptake and transport in plants. FEBS Lett 581:2273-2280. https://doi.org/10.1016/j.febslet. 2007.04.043

Kosegarten H, Koyro HW (2001) Apoplastic accumulation of iron in the epidermis of maize (Zea mays) roots grown in calcareous soil. Physiol Plant 113:515-522. https://doi.org/10.1034/j.1399-3054. 2001.1130410.x

Lee A (1998) How lipids interact with an intrinsic membrane protein: the case of the calcium pump. Biochim Biophys Acta - Rev Biomembr 1376:381-390. https://doi.org/10.1016/S0304-4157(98)00010-0
Lucena C, Romera FJ, Rojas CL, García MJ, Alcántara E, Pérez-Vicente R (2007) Bicarbonate blocks the expression of several genes involved in the physiological responses to Fe deficiency of strategy I plants. Funct Plant Biol 34:1002. https://doi.org/10.1071/FP07136

Marschner H (2012) Marschner's mineral nutrition of higher plants. 3rd edition. Academic press

Martínez-Cuenca M-R, Iglesias DJ, Forner-Giner MA, Primo-Millo E, Legaz F (2013) The effect of sodium bicarbonate on plant performance and iron acquisition system of FA-5 (Forner-Alcaide 5) citrus seedlings. Acta Physiol Plant 35:2833-2845

Mengel K (1994) Iron availability in plant tissues-iron chlorosis on calcareous soils. Plant Soil 165:275-283. https://doi.org/10.1007/ BF00008070

Michel L, Beyá-Marshall V, Rombolà AD, Pastenes C, Covarrubias JI (2019) Evaluation of FE-heme applications or intercropping for preventing Iron deficiency in blueberry. J Soil Sci Plant Nutr 19: 117-126. https://doi.org/10.1007/s42729-019-0017-9

Neumann G, Römheld V (2012) Marschner's mineral nutrition of higher plants, Marschner's mineral nutrition of higher plants. Academic Press. doi https://doi.org/10.1017/CBO9781107415324.004

Nikolic M, Römheld V (2002) Does high bicarbonate supply to roots change availability of iron in the leaf apoplast? Plant Soil 241:6774. https://doi.org/10.1023/A:1016029024374

Nikolic M, Römheld V (2007) The dynamics of iron in the leaf apoplast. In: The Apoplast of higher plants: compartment of storage, transport and reactions. Springer Netherlands, Dordrecht, pp. 353-371. doi https://doi.org/10.1007/978-1-4020-5843-1_26

Ollat N, Laborde B, Neveux M, Diakou-Verdin P, Renaud C, Moing A (2003) Organic acid metabolism in roots of various grapevine (Vitis) rootstocks submitted to iron deficiency and bicarbonate nutrition. J Plant Nutr 26:2165-2176

Osório ML, Osório J, Vieira AC, Gonçalves S, Romano A (2011) Influence of enhanced temperature on photosynthesis, photooxidative damage, and antioxidant strategies in Ceratonia siliqua L. seedlings subjected to water deficit and rewatering. Photosynthetica 49: 3-12. https://doi.org/10.1007/s11099-011-0001-7

Paiva EAS (2019) Are calcium oxalate crystals a dynamic calcium store in plants? New Phytol 223:1707-1711. https://doi.org/10.1111/nph. 15912

Pestana M, De Varennes A, Abadía J, Faria EA (2005) Differential tolerance to iron deficiency of citrus rootstocks grown in nutrient solution. Sci Hortic (Amsterdam) 104:25-36. https://doi.org/10.1016/j. scienta.2004.07.007

Pestana M, Faria EA, de Varennes A (2004) Lime-induced iron chlorosis in fruit trees. In: Dris R., Jain S.M. (eds) Production practices and quality assessment of food crops. Springer Dordrecht, pp. 171-215. https://doi.org/10.1007/1-4020-2536-x 7

Pestana M, Gama F, Saavedra T, De Varennes A, Correia PJ (2012) The root ferric-chelate reductase of Ceratonia siliqua (L.) and Poncirus trifoliata (L.) Raf. responds differently to a low level of iron. Sci Hortic (Amsterdam) 135:65-67

Pestana M, Correia PJ, Saavedra T, Gama F, Dandlen S, Nolasco G, de Varennes A (2013) Root ferric chelate reductase is regulated by iron and copper in strawberry plants. J Plant Nutr 36:2035-2047. https:// doi.org/10.1080/01904167.2013.816731

Pfaffl MW (2001) A new mathematical model for relative quantification in real-time RT-PCR. Nucleic Acids Res 29:e45

Rhizopoulou S (2004) Aspects of cell wall extensibility in Ceratonia siliqua L. Flora - Morphol Distrib Funct Ecol Plants 199:327-333. https://doi.org/10.1078/0367-2530-00160

Rombolà AD, Brüggemann W, López-Millán AF, Tagliavini M, Abadía J, Marangoni B, Moog PR (2002) Biochemical responses to iron deficiency in kiwifruit (Actinidia deliciosa). Tree Physiol 22:869 875. https://doi.org/10.1093/treephys/22.12.869 
Römheld V, Nikolic M (2007) Iron. In: Barker AV, Pilbeam DJ (eds) Handbook of plant nutrition. CRC Press, Taylor and Francis Inc., New York, pp 329-350

Shevela D, Eaton-Rye JJ, Shen JR, Govindjee (2012) Photosystem II and the unique role of bicarbonate: a historical perspective, In: Biochimica et Biophysica Acta - Bioenergetics., 1817(8): pp. 1134-1151. https://doi.org/10.1016/j.bbabio.2012.04.003

Susin S, Abadía A, Gonzalez-Reyes JA, Lucena JJ, Abadia J (1996) The $\mathrm{pH}$ requirement for in vivo activity of the iron-deficiency-induced "turbo" ferric chelate reductase. A comparison of the irondeficiency-induced iron reductase activities of intact plants and isolated plasma membrane fractions in sugar beet. Plant Physiol 110: 111-123. https://doi.org/10.1104/pp.110.1.111

Tomasi N, Mimmo T, Terzano R, Alfeld M, Janssens K, Zanin L, Pinton R, Varanini Z, Cesco S (2014) Nutrient accumulation in leaves of Fe-deficient cucumber plants treated with natural Fe complexes. Biol Fertil Soils 50:973-982. https://doi.org/10.1007/s00374-0140919-6

Venturas M, Fernández V, Nadal P, Guzmán P, Lucena JJ, Gil L (2014) Root iron uptake efficiency of Ulmus laevis and U. minor and their distribution in soils of the Iberian Peninsula. Front Plant Sci 5(104). https://doi.org/10.3389/fpls.2014.00104

Virdi AS, Singh S, Singh P (2015) Abiotic stress responses in plants: roles of calmodulin-regulated proteins. Front Plant Sci 6. https://doi.org/ 10.3389/fpls.2015.00809

Wegner LH, Zimmermann U (2004) Bicarbonate-induced alkalinization of the xylem sap in intact maize seedlings as measured in situ with a novel xylem pH probe. Plant Physiol 136:3469-3477

Wu YY, Xing DK (2012) Effect of bicarbonate treatment on photosynthetic assimilation of inorganic carbon in two plant species of Moraceae. Photosynthetica 50:587-594. https://doi.org/10.1007/ s11099-012-0065-z

Yunta F, Sierra MA, Gómez-Gallego M, Alcázar R, García-Marco S, Lucena JJ (2003) Methodology to screen new iron chelates: prediction of their behavior in nutrient solution and soil conditions. J Plant Nutr 26:1955-1968. https://doi.org/10.1081/PLN-120024256

Publisher's note Springer Nature remains neutral with regard to jurisdictional claims in published maps and institutional affiliations. 